\title{
The Impact of Health Education Program about the Safe Use of Pesticides among Farmers at a Village in El-Minia City
}

\author{
Manar Demein Mohammed1, Soheir Ali Bader EL-Din2, Refaat Raouf Sadek3, Awatf Abdelrazek Mohammed4
}

1. Assistant lecturer of Community Health Nursing, Faculty of Nursing, Minia University, Egypt.

2. Professor of Community Health Nursing, Faculty of Nursing, Cairo University, Egypt.

3. Head of Community Medicine department, Faculty of Medicine - Minia University, Egypt

4. Professor of Community Health Nursing, Faculty of Nursing, Minia University, Egypt

\begin{abstract}
Background: Globally, pesticides poisonings and its side reactions are dramatically effecting the agricultural sector that accounted for between 250,000 to 370,000 human deaths annually, most of these deaths occurred in developing countries. Aim: Study aims to assess the impact of health education program on the safe use of pesticides for farmers at a village of El-Minia city. Design: Quasi-experimental design was utilized for this study with pre/posttest. A simple random sample of 322 pesticides users was selected. Data were collected through one tool that includes; 1st. part; questions related to demographic characteristics of the study sample, 2nd. part; knowledge questionnaire related to the using of pesticides in general, and the knowledge regarding the first aid of pesticide poisoning, 3rd. part; an attitudes regarding the usage of pesticides and the 4th .part; was a self-reported practices use of pesticides among farmers. Results: the mean age of the farmers who participated in the study was $47.7 \pm 8.3$ and $53.4 \%$ of them were illiterates. The current study showed that the general knowledge and also the first aid knowledge among studied sample were improved; from $7.8 \%$ and $23.6 \%$ respectively before implementation of the program to $69.3 \%$ and $90.4 \%$ have high level after implementation of the program. Farmers' attitudes revealed that an improvement from $13.4 \%$ of farmers before implementation of the program to $80.4 \%$ of the farmers have positive attitude. Regarding the reported practice; $79.8 \%$ have poor practice before implementation of the program improved to $63.4 \%$ fair practice after implementation of the program. Conclusion: Statistically significant relationships were found of general knowledge of studied farmers, attitudes and their self- reported practice regarding safety using of pesticides after the implementation of the health education program. Recommendations: continuous training and health education for Egyptian farmers are essential for safe practices during pesticides' usage also further researches are needed.
\end{abstract}

Keywords: Safe use of pesticides, Health education Program

\section{Introduction:}

A pesticide is a substance or mixture of substances intended for preventing, destroying, repelling or mitigating any pest, pesticides are usually used by farmers to prevent fungal invasion, insect damage, and the growth of unwanted (and often poisonous) plants. Pesticide has a positive benefit in terms of public health because fungi, insects and non-crop plants can contaminate crops with many natural toxins injurious to health (1). Pesticides are widely used throughout the world, especially in agriculture for crop protection. Millions of farmers are exposed to danger by hazardous occupational practices and unsafe storage. Exposure to chemical pesticides is one of the most important occupational risks among farmers in the developing countries. Farmers can easily come in contact with the pesticides, for example, when mixing the chemicals or when applying them to the crops and when pesticide residues are carried to home (2).

\section{Significant of study:}

According to World Health Organization, each year, about $3,000,000$ cases of pesticide poisoning and 220,000 deaths are reported in developing countries. About 2.2 million people, mainly belonging to developing countries are at increased risk of exposure to pesticides. Besides, some people are more susceptible to the toxic effects of pesticide than others, such as infants, young $\mathrm{P}$ a g e $\mid \mathbf{8 8}$ children, agricultural farm workers and pesticide applicators (Pesticides and Human Health (3). Nearly $80 \%$ of work force in Egypt are involved in agriculture and exposed to agriculture aerosols. Unlike other occupation they live in the same environment and thus exposure for them and their children continue over the weak. Agriculture workers and those living in rural environment are at increased risk of developing lung diseases (4).

\section{Aim of the Study (It is two-folded aim):}

- To assess the knowledge, attitudes, and selfreported practices regarding the safe use of pesticide among farmers in El-Minia city, Minia, Egypt.

- To assess the impact of health education program on the Safe Use of Pesticides for Farmers at a Village in El-Minia city. Egypt.

\section{Research hypothesis:}

Implementation of health education program regarding the safe use of pesticide among farmers in a village of El-Minia city will improve the knowledge, attitudes, and self-reported practices of the study group. 


\section{Subjects and Methods}

\section{Research Design:}

Quasi-experimental design (Pretest Post-Test) was utilized in this research study.

\section{Research Setting:}

The study was conducted in one randomly selected village of El-Minia city at minia governorate, Egypt. Simple random sample technique was used to select one village (Damaris village) in El-Minia city.

\section{Sample of the study:}

The sample size was estimated to fulfill the aim of the study, with a $95 \%$ level of confidence (error=5\%) and a study power of $80 \%$ (error $=20 \%$ ). By using the Epi-info computer software program the required sample size was 322 farmers.

\section{Study Tool:}

A Structured questionnaire was designed by the researcher regarding the safe use of pesticides after reviewing of literature related to the study topic; also this tool was adapted from other instrument used by Norkaew (2009) and some modification were done by the researcher. The tool contents were tested for validity by three experts in community health nursing and community medicine and modification were done accordingly to ascertain relevance and completeness.

\section{This tool includes four parts:}

\section{1st part: Demographics characteristics}

The first part was designed to assess demographic and occupational characteristics of the farm workers such as (age, level of education, experience, working hours

\section{2nd part: Knowledge regarding using of pesticide, it} consist of:-

- General knowledge regarding using of pesticide (10 questions)

(Knowledge of using pesticide, personal protective equipment, health effect of pesticides What is disadvantage of pesticide use, How to use the pesticide properly, When you want to buy pesticide, how do you consider, .etc.).

- Knowledge regarding first aid of pesticide poisoning (8 questions)

(Routes of entering of pesticides to the body, S\&s of pesticides poisoning, first aid of pesticides poisoning). A correct answer will give 1 score and 0 score for wrong answer. Scores Descriptions: - (Less than 59\%) Low level, (60-80\%) Moderate levels and (80-100\%) High levels).

\section{3rd part: Attitudes regarding using of pesticide (15 questions)}

Farmers respond to 5 statements are a Likert's scale. The rating scale is measure as follow: (Strongly agree $=4$, Agree $=3$, Neural $=2$, disagree $=1$ and strongly disagree $=0$ ). The scores were classified into 3 levels (Positive Attitude (80\%-100\%), Neutral Attitude (60\%$80 \%$ ), and Negative Attitude (Less than 59\%).

\section{4th part: Self-reported Practice of pesticide usage (23 questions)}

This 4th. Part includes questions about selfreported practices; how often they use each personal protective equipment. There were 4 statements. The rating scale is measure as follow: Usually $=4$, Sometime $=3$, rarely $=2$, Never $=1$. These classified into 3 levels (Good Practice $(80 \%-100 \%)$, Fair Practice $(60 \%-80 \%)$ and Poor Practice (Less than 59\%).

\section{Content Validity:}

The content validity of the data collection tool was determined through an extensive review of national and international literature related to safe use of pesticides. The 4 parts of the tool were submitted to three experts in community health nursing and community medicine to test their validity. The tool was examined for content coverage, sequence of items, clarity, relevance, applicability, wording, length, format, and overall appearance. Based on experts` comments and recommendations; minor modifications had been made such as rephrasing and rearrangements of some sentences.

\section{Reliability:}

The internal consistency of the questionnaires was calculated using Cronbach's alpha coefficients. Test-retest was used. The Cronbach's alpha of the questionnaires were $0.87,0.97$ and 0.96 respectively indicate good reliability.

\section{Pilot study}

To assess the clarity, reliability and applicability of the study tools which was used in the study for data collection; a pilot study was conducted on $10 \%$ of the sample. The results of the pilot study was helped in the necessary modifications of the tools in which omission of unneeded or repeated questions, adding missed questions will be done.

\section{Statistical Analysis}

Statistical package for the social science SPSS version 21 was used for statistical analysis of data, as it contains the test of significance given in standard statistical books. Collected data was summarized and tabulated.

\section{Ethical consideration}

Informed verbal consent will be obtained from farmers to be included in the study. It was included full explanation of the sheet, rights for privacy, confidentiality and rights to withdraw at any time. 


\section{Procedure}

- A review of the related literature which was covering various aspects of the problem has done, using different books, journals and web sites, to get acquainted with the research problem and to implement the study

- An official permission taken from the dean of the faculty for conducting the study.

- An official letter from the faculty of nursing was delivered to the director (s) of the intended study setting (agricultural unit in the selected village).

- Verbal informed consents were obtained from all the farmers before the program enrollments. After that; a detailed explanation on study objectives was done.

- $\quad$ The program lasted for 6 months; the study started at the beginning of September 2016, and was completed by the end of February 2017.

- Data were collected from each farmer individually before the implementation of the program for pretest was collected by using the previous mentioned study tool. These lasted for 20 to 30 minutes for each one; The researcher divided the farmers into ten groups related to their time which was not interfere with their work time, Each group was from 30 to 32 farmers each session was conducted for about two to three hours for each group in agricultural unit of the Damaris village. then the researcher has agreed with farmers on the date of assembly for each group at the agricultural unit (ElGamaia ElZeraia) in the village of Damaris to implement the sessions of the health education program.

- The program sessions were consist of 5 sessions for each farmers 'group using of a variety of teaching methods such as group discussion, lectures, role play and teaching videos each session lasted for 1530 minutes with total time duration of three hours for each group started from 9 am to 12 midday. The researcher conducted the same previous sessions for the other 9 groups in the same way with different date suitable to farmers' time.

- At the beginning of each session; the objective of the session explained. Also Feedback was done about the previous session and the content of the session were dealt using different ways of teaching. While the practical part of the teaching program was done for each session that corresponding with session contents

- Each session followed by a summary of essential points.

- At the end of program sessions, data were immediately collected using the study tool as a post-test, after three months also data were collected for follow-up test to show the effectiveness of the implemented program.

\section{Results}

Table (1) Distribution of the studied sample pesticides farmers according to their socio- demographic characteristics: (N. =322):-

\begin{tabular}{|c|c|c|}
\hline Socio-demographic characteristics & No. & $\%$ \\
\hline age & & \\
\hline $10-20$ years & 24 & 7.4 \\
\hline $21-40$ & 83 & 25.8 \\
\hline $41-60$ & 157 & 48.8 \\
\hline$>61$ & 58 & 18.0 \\
\hline $47.7 \pm 8.3$ & & \\
\hline Level of education & & \\
\hline Illiterate & 172 & 53.4 \\
\hline Read and write & 64 & 19.9 \\
\hline Below university & 48 & 14.9 \\
\hline University & 38 & 11.8 \\
\hline income/ month & & \\
\hline$>2000$ L.E & 208 & 64.6 \\
\hline 2000-5000 L.E & 79 & 24.5 \\
\hline$<5000$ L.E & 35 & 10.9 \\
\hline years expos to pesticides & & \\
\hline $1-5$ years & 56 & 17.4 \\
\hline $6-10$ years & 125 & 38.8 \\
\hline$>10$ years & 141 & 43.8 \\
\hline
\end{tabular}




\begin{tabular}{|c|c|c|}
\hline Socio-demographic characteristics & No. & $\%$ \\
\hline Mean \pm SD & & \\
\hline \multicolumn{3}{|l|}{ Previous training } \\
\hline yes & 75 & 23.3 \\
\hline no & 247 & 76.7 \\
\hline \multicolumn{3}{|l|}{ source of pesticide information } \\
\hline Media & 37 & 11.5 \\
\hline Label & 0 & 0 \\
\hline neighbors & 30 & 9.3 \\
\hline agricultural supervisors & 85 & 26.4 \\
\hline pesticides salesman & 170 & 52.8 \\
\hline
\end{tabular}

Table (1) showed that socio demographic characteristics of pesticides' users, nearly half $(48.8 \%)$ of pesticides' farmers were in the age group from41-60 years with mean age Mean \pm SD $47.7 \pm 8.3,53.4 \%$ of farmers were illiterate and $64.6 \%$ of the respondents had an income

less than 2000 bound. years of exposure to pesticides $(<10$ years) were $(43.8 \%)$, and $(76.7 \%)$ have no previous training about safe use of pesticides, and nearly half of participants $(52.8 \%)$ take their information about the pesticide from pesticides salesman.

Fig. 1 Changes in knowledge, attitude and practice mean scores from pretest to post and follow-up test

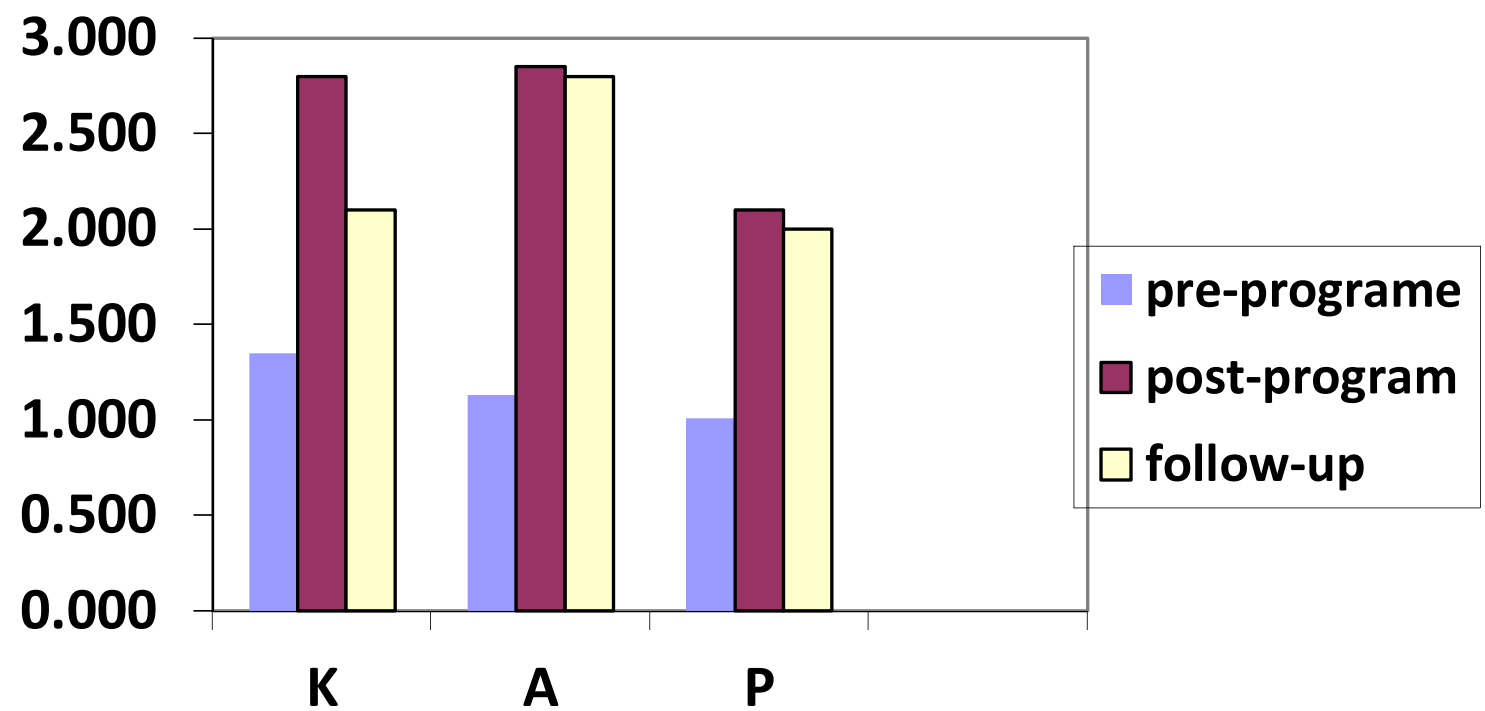

Fig.1 illustrate that The total KAP mean scores at different levels of study, there was a significant improvement $(\mathrm{P}<0.001)$ in the total KAP mean score during posttest (7.53 \pm 1.056$)$ and follow-up test $(7.26 \pm 1.261)$ as compared to pretest $(3.51 \pm .858)$. Knowledge scores significantly improved from $(2.8 \pm 0.41)$ in posttest to $(2.0 \pm 0$ $.34)$ in follow-up test as compared to (1.35 \pm 0.62$)$ in pre-test.

Also there was a significant improvement in attitude score from $(2.85 \pm 0.35)$ in posttest to $(2.8 \pm 0.41)$ as compared to pretest $(1.13 \pm 0.34)$. And there was a significant improvement in practice score from $(2.1 \pm 0.6)$ in posttest to $(2.1 \pm 0.6)$ in follow-up test as compared to pretest $(1.01 \pm 0.12)$.

Table (2) Correlations between knowledge, attitudes and reported practices of farmers after implementation of the health education program

\begin{tabular}{|l|l|l|l|}
\hline Variables & Knowledge & Attitudes & Practices \\
\hline Knowledge & & & \\
r.Value & 1 & .239 & .108 \\
P.Value & - & $.000^{* *}$ & .053 \\
\hline Attitudes & & & \\
r.Value & .239 & 1 & .350 \\
P.Value & $.000^{* *}$ & - & $.000^{* *}$ \\
\hline
\end{tabular}




\begin{tabular}{|l|l|l|l|}
\hline Variables & Knowledge & Attitudes & Practices \\
\hline Practices & & & \\
r.Value & .108 & .350 & 1 \\
P.Value & .053 & $.000^{* *}$ & - \\
\hline
\end{tabular}

Table (2) revealed that there were positive statistically significant correlation between knowledge,

attitudes and self-reported practices of pesticides' farmers after implementation of health education program.

Table (3): The relationship between total knowledge and socio-demographic characteristics before and after the implementation of the program $(\mathrm{N}=322)$ :-

\begin{tabular}{|c|c|c|c|c|}
\hline \multirow[t]{2}{*}{ Variable } & \multicolumn{2}{|c|}{ Preprogram knowledge } & \multicolumn{2}{|c|}{ post program knowledge } \\
\hline & Mean \pm SD & $\mathrm{P}$ & Mean \pm SD & $\mathrm{P}$ \\
\hline $\begin{array}{l}\text { Age group } \\
10-20 \\
21-40 \\
41-60 \\
>61\end{array}$ & $\begin{array}{l}4.71 \pm 3.4 \\
3.13 \pm 3.1 \\
3.67 \pm 2.93 \\
1.72 \pm 2.1\end{array}$ & $0.000^{*}$ & $\begin{array}{l}9.04 \pm 2.44 \\
8.43 \pm 2.46 \\
8.25 \pm 2.65 \\
7.90 \pm 3.2\end{array}$ & $0.34 *$ \\
\hline $\begin{array}{l}\text { Status in family } \\
\text { One of sons } \\
\text { Head of family }\end{array}$ & $\begin{array}{l}4.43 \pm 3.31 \\
3.17 \pm 2.9\end{array}$ & $0.05 * *$ & $\begin{array}{l}r, 0 \pm 9 \\
8.24 \pm 2.7\end{array}$ & $0.19 * *$ \\
\hline $\begin{array}{l}\text { Level of education } \\
\text { Illiterate } \\
\text { Read and write } \\
\text { Diploma } \\
\text { High education }\end{array}$ & $\begin{array}{l}1.78 \pm 2.03 \\
2.84 \pm 2.37 \\
5.94 \pm 2.24 \\
7.26 \pm 2.19\end{array}$ & $0.000 *$ & $\begin{array}{l}7.8 \pm 2.99 \\
8.21 \pm 2.73 \\
9.08 \pm 1.74 \\
9.63 \pm 1.20\end{array}$ & $0.0001 *$ \\
\hline $\begin{array}{l}\text { income/ month } \\
<2000 \text { L.E } \\
\text { 2000-5000 L.E } \\
>5000 \text { L.E }\end{array}$ & $\begin{array}{l}3.25 \pm 2.94 \\
3.42 \pm 2.92 \\
2.91 \pm 3.18\end{array}$ & $0.71 *$ & $\begin{array}{l}8.15 \pm 2.75 \\
8.82 \pm 2.08 \\
7.94 \pm 3.46\end{array}$ & $0.12 *$ \\
\hline $\begin{array}{l}\text { Years of exposure to pesticides } \\
-5 \text { years } \\
6-10 \text { years } \\
>10 \text { years }\end{array}$ & $\begin{array}{l}3.38 \pm 3.14 \\
3.68 \pm 2.84 \\
2.84 \pm 2.95\end{array}$ & $0.06^{*}$ & $\begin{array}{l}r, l \pm 9, l \\
r, \vee r \pm V, q 9 \\
r, \wedge \leq \pm \wedge, r \leq\end{array}$ & $0.04 *$ \\
\hline $\begin{array}{l}\text { Previous training } \\
\text { Received } \\
\text { Not received }\end{array}$ & $\begin{array}{l}6.44 \pm 2.22 \\
1.9 \pm 2.06\end{array}$ & $\begin{array}{l}0.0001^{*} \\
*\end{array}$ & $\begin{array}{l}9.28 \pm 1.54 \\
7.88 \pm 2.97\end{array}$ & $0.0001 * *$ \\
\hline
\end{tabular}

\section{N.B $*$ F-value $\quad * *$ T-value}

Table (3): Shows that there were highly statistical significant differences between total knowledge and socio demographic characteristics of the studied sample related to age in pretest only, and with level of education and previous training in pretest and posttest respectively.

Table (4): The relationship between total attitude and socio-demographic characteristics before and after the implementation of the program $(\mathrm{N}=322)$ :-

\begin{tabular}{|c|c|c|c|c|}
\hline \multirow[t]{2}{*}{ Variable } & \multicolumn{2}{|c|}{ Preprogram attitude } & \multicolumn{2}{|c|}{ Post program attitude } \\
\hline & mean & $\mathrm{P}$ value & mean & $\mathrm{P}$ value \\
\hline Age group & & & & \\
\hline $10-20(1)$ & $24.9 \pm 11.77$ & & $58.46 \pm 3.3$ & \\
\hline $21-40(2)$ & $20.6 \pm 11.5$ & $\cdot, \ldots 1 *$ & $55.65 \pm 5.79$ & $\cdot, \ldots 1 *$ \\
\hline $41-60(3)$ & $20.76 \pm 12.0$ & & $56.29 \pm 5.1$ & \\
\hline$>61(4)$ & $15.2 \pm 5.7$ & & $53.28 \pm 6.2$ & \\
\hline Status in family & & & $r, r v \pm 0 \wedge, r q$ & \\
\hline
\end{tabular}




\begin{tabular}{|c|c|c|c|c|}
\hline \multirow[t]{2}{*}{ Variable } & \multicolumn{2}{|c|}{ Preprogram attitude } & \multicolumn{2}{|c|}{ Post program attitude } \\
\hline & mean & $P$ value & mean & $\mathrm{P}$ value \\
\hline $\begin{array}{l}\text { One of sons } \\
\text { Head of family }\end{array}$ & $\begin{array}{l}24.57 \pm 11.9 \\
19.68 \pm 11.1\end{array}$ & $0.0 \leqslant * *$ & $55.54 \pm 5.59$ & $0.001 * *$ \\
\hline $\begin{array}{l}\text { Level of education } \\
\text { Illiterate } \\
\text { Read and write } \\
\text { Diploma } \\
\text { High education }\end{array}$ & $\begin{array}{l}14.27 \pm 2.97 \\
12.73 \pm 2.98 \\
31.02 \pm 4.57 \\
44.5 \pm 0.51\end{array}$ & $\cdot, \ldots 1 *$ & $\begin{array}{l}52.56 \pm 5.62 \\
59.27 \pm 2.63 \\
59.23 \pm 1.65 \\
59.84 \pm 0.97\end{array}$ & $\cdot,+1 *$ \\
\hline $\begin{array}{l}\text { income/ month } \\
<2000 \text { L.E } \\
\text { 2000-5000 L.E } \\
>5000 \text { L.E }\end{array}$ & $\begin{array}{l}19.17 \pm 10.6 \\
22.1 \pm 11.7 \\
20.46 \pm 13.3\end{array}$ & $\cdot, 1 \leq *$ & $\begin{array}{l}55.67 \pm 5.55 \\
56.70 \pm 4.59 \\
54.06 \pm 6.79\end{array}$ & $\cdot, .7 *$ \\
\hline $\begin{array}{l}\text { Years of exposure to pesticides } \\
-5 \text { years } \\
6-10 \text { years } \\
>10 \text { years }\end{array}$ & $\begin{array}{l}21.7 \pm 11.1 \\
21.04 \pm 12.1 \\
18.45 \pm 10.3\end{array}$ & $\cdot, \cdot \wedge *$ & $\begin{array}{l}0, \Gamma) \pm 07, Y 0 \\
0,1 \wedge \pm 07,0 . \\
54.88 \pm 5.78\end{array}$ &., $.0 *$ \\
\hline $\begin{array}{l}\text { Previous training } \\
\text { Received } \\
\text { Not received }\end{array}$ & $\begin{array}{l}34.5 \pm 10.2 \\
13.87 \pm 3.06\end{array}$ & $0.0001 * *$ & $\begin{array}{l}58.94 \pm 2.9 \\
54.39 \pm 5.79\end{array}$ & $0.001 * *$ \\
\hline
\end{tabular}

\section{N.B $*$ F-value $\quad * *$ T-value}

Table (4): Indicates that there were highly statistical significant differences between total attitude and socio demographic characteristics of the studied sample related to age, level of education, status in family and previous training in pre and posttest respectively.

Table (5): The relationship between total practice and socio-demographic data before and after the implementation of the program $(\mathbf{N}=322)$ :-

\begin{tabular}{|c|c|c|c|c|}
\hline \multirow[t]{2}{*}{ Variable } & \multicolumn{2}{|c|}{ preprogram practice } & \multicolumn{2}{|c|}{ Post program-practice } \\
\hline & mean & $\mathrm{P}$ value & mean & $\mathrm{P}$ value \\
\hline \multicolumn{5}{|l|}{ Age group } \\
\hline $10-20$ & $48.75 \pm 11.1$ & \multirow{4}{*}{$\cdot, \ldots) *$} & $83.04 \pm 6.9$ & \multirow{4}{*}{$0.0001 *$} \\
\hline $21-40$ & $43.72 \pm 11.6$ & & $78.58 \pm 8.7$ & \\
\hline $41-60$ & $43.74 \pm 11.0$ & & $79.33 \pm 8.3$ & \\
\hline$>61$ & $36.79 \pm 6.2$ & & $73.98 \pm 8.5$ & \\
\hline \multicolumn{5}{|l|}{ Status in family } \\
\hline One of sons & $48.26 \pm 11.1$ & \multirow[t]{2}{*}{$0.01 * *$} & $82.78 \pm 6.9$ & \multirow[t]{2}{*}{$0.01 * *$} \\
\hline Head of family & $42.44 \pm 10.8$ & & $78.12 \pm 8.7$ & \\
\hline \multicolumn{5}{|l|}{ Level of education } \\
\hline Illiterate & $36.7 \pm 4.6$ & \multirow{4}{*}{$\cdot, \ldots, *$} & $V, \wedge \pm V \leq, T V$ & \multirow{4}{*}{$\cdot, \ldots 1 *$} \\
\hline Read and write & $37 \pm 4.06$ & & $0, T r_{ \pm} V_{0, \Sigma v}$ & \\
\hline Diploma & $57.79 \pm 3.6$ & & $r, r \pm \wedge \wedge, \cdot r$ & \\
\hline High education & $61.68 \pm 2.78$ & & $88.45 \pm 1.93$ & \\
\hline \multicolumn{5}{|l|}{ income/ month } \\
\hline$<2000$ L.E & $41.77 \pm 10.6$ & \multirow{3}{*}{$0.06^{*}$} & $78.29 \pm 8.3$ & \multirow[t]{3}{*}{$0.49 *$} \\
\hline 2000-5000 L.E & $44.85 \pm 11.4$ & & $79.34 \pm 9.3$ & \\
\hline$>5000$ L.E & $44.8 \pm 11.34$ & & $77.4 \pm 9.29$ & \\
\hline \multicolumn{5}{|l|}{ Years of exposure to pesticides } \\
\hline-5 years & $45.09 \pm 11.2$ & \multirow{3}{*}{$\cdot, \cdot 7 *$} & $80.2 \pm 8.5$ & \multirow[t]{3}{*}{$0.05 *$} \\
\hline $6-10$ years & $44.1 \pm 11.3$ & & $79.07 \pm 8.5$ & \\
\hline$>10$ years & $40.87 \pm 10.1$ & & $77.20 \pm 8.7$ & \\
\hline
\end{tabular}




\begin{tabular}{|l|l|l|l|l|}
\hline Variable & \multicolumn{2}{|l|}{ preprogram practice } & \multicolumn{2}{l|}{ Post program-practice } \\
\cline { 2 - 5 } & mean & P value & mean & P value \\
\hline Previous training & & & & \\
Received & $56.98 \pm 8.4$ & $0.001^{* *}$ & $86.45 \pm 6.15$ & $0.000^{* *}$ \\
Not received & $36.86 \pm 4.4$ & & $75.05 \pm 7.22$ & \\
\hline
\end{tabular}

\section{N.B * F-test $\quad * *$ T-test}

Table (5): Denotes that there were highly statistical significant differences between total practice and socio demographic characteristics of the studied sample related to age group, level of education, Status in family and previous training in pre and posttest respectively.

Table (6): Multiple linear regression analysis illustrates the effect of different variables on pre and posttest total mean score of knowledge, attitude and practice:

\begin{tabular}{|c|c|c|c|c|c|c|c|c|c|c|c|c|}
\hline \multirow[t]{2}{*}{ Variable } & \multicolumn{2}{|c|}{$\begin{array}{l}\text { Preprogram total } \\
\text { mean score } \\
\text { knowledge }\end{array}$} & \multicolumn{2}{|c|}{$\begin{array}{l}\text { Post- program } \\
\text { knowledge }\end{array}$} & \multicolumn{2}{|c|}{$\begin{array}{l}\text { Preprogram } \\
\text { attitude }\end{array}$} & \multicolumn{2}{|c|}{$\begin{array}{l}\text { Post program } \\
\text { attitude }\end{array}$} & \multicolumn{2}{|c|}{$\begin{array}{l}\text { Preprogram } \\
\text { practice }\end{array}$} & \multicolumn{2}{|c|}{$\begin{array}{l}\text { Post program } \\
\text { practice }\end{array}$} \\
\hline & Beta & $P$ value & Beta & $P$ value & Beta & $\mathrm{P}$ value & Beta & $P$ value & Beta & P value & Beta & $P$ value \\
\hline User age & 0.06 & 0.45 & 0.02 & 0.81 & 0.05 & 0.6 & 0.00 & 0.97 & 0.05 & 0.6 & 0.06 & 0.37 \\
\hline Status in family & 0.03 & 0.59 & 0.03 & 0.56 & 0.03 & 0.61 & 0.02 & 0.73 & 0.03 & 0.613 & 0.05 & 0.26 \\
\hline $\begin{array}{ll}\begin{array}{l}\text { Level } \\
\text { education }\end{array} & \text { of }\end{array}$ & 0.34 & $0.0001^{*}$ & 0.08 & 0.42 & 0.33 & $0.001 *$ & 0.44 & $0.001 *$ & 0.33 & $0.001 *$ & 0.42 & $0.001 *$ \\
\hline User income & 0.05 & 0.23 & 0.04 & 0.41 & 0.24 & $0.0001 *$ & 0.05 & 0.33 & 0.24 & $0.0001^{*}$ & 0.02 & 0.58 \\
\hline Years of exposure & 0.11 & 0.17 & 0.03 & 0.69 & 0.01 & 0.87 & 0.01 & 0.84 & 0.01 & 0.872 & 0.09 & 0.12 \\
\hline Previous training & 0.20 & $0.03 *$ & 0.10 & 0.33 & 0.07 & $0.001^{*}$ & 0.16 & 0.11 & 0.07 & $0.001 *$ & 0.34 & $0.001 *$ \\
\hline $\begin{array}{ll}\text { Source } & \text { of } \\
\text { information }\end{array}$ & 0.08 & 0.12 & 0.02 & 0.76 & 0.08 & 0.14 & 0.07 & 0.16 & 0.08 & 0.14 & 0.03 & 0.47 \\
\hline
\end{tabular}
$0.13 \& 0.56)$.

Regression used is linear regression ( $\mathrm{R} 2$ for knowledge $=0.28 \& 0.04)(\mathrm{R} 2$ for attitude $=0.59 \& 0.12)(\mathrm{R} 2$ for practice $=$

In table (6) illustrates that the level of user education and perceived previous training were the most effective predictors that enhance the knowledge of safe usage of pesticides in preprogram. Also the level of user education was the most effective predictor that enhance the

\section{Discussion}

These study discussion is presented according to the aim of the study that to assess the impact of health education program on the safe use of pesticides for farmers. The widely used of pesticides in Egypt denotes the lack of rigorous legislation and regulations to control pesticides also it led to the widespread availability and unrestricted use. Farmers are exposed to serious health problems due to lack of knowledge, negative attitude and poor practices of using pesticides .pesticides poisonings in agricultural sector indicates many deaths and associated health problems among farmers. Therefore health education program for Pesticide safety training is vital for workers. Hence, the researcher keen to implement this study to evaluate the impact of health education program on the safe use of pesticides for farmers.

In relation to the total KAP scores at different levels of study there was a highly significant improvement $(\mathrm{P}<0.001)$ in the total KAP scores during first assessment $(7.53 \pm 1.056)$ and second assessment $(7.26 \pm 1.261)$ as compared to baseline level (3.51 .858). Lightly decrease attitude of safe usage of pesticides in pre and post-program. Regarding practice towards safe usage of pesticides; the level of user education, user income, and perceived previous training were the most effective predictors that enhance their practice in pre and post-program.

also denoted in total KAP scores from first to second assessment indicating that there was decrease in retention of knowledge, attitude and practice. These results come in harmony with findings of Sam et al (2008) in India, found that there was a highly significant improvement $(\mathrm{P}<0.001)$ in the total KAP scores during first assessment (45.03 \pm 9.16) and second assessment (42.91 \pm 9.54$)$ as compared to baseline level $(30.88 \pm 10.33)$. A significant decrease $(\mathrm{P}<$ 0.05 ) was also observed in total KAP score from first to second assessment indicating that there was a decrease in retention of knowledge, attitude and practice. From researcher point of view, the increase of knowledge in posttest attributed to the planned teaching and training program which was effective in improving the knowledge of the study farmers. Therefore, it is important for farmers who used pesticides to understand safe usage of pesticides, prevention of pesticides poisoning, environmental sanitation, in order to improve farmer's health and prevent pesticides complications. The decline in farmers KAP between posttest and follow-up test, may be related to the study sample age and the educational levels. 
In current study results showed that there were highly statistical significant differences between total knowledge and some of socio demographic characteristics of the studied sample such level of education and the previous training. As Gaber and Abdel-Latif (2012) in their study about" Effect of education and health locus of control on safe use of pesticides a cross sectional random study" showed that farmers who received school education had higher levels of knowledge.

Receiving previous training with total knowledge in current study pointed out highly statistical significant differences the results were similar to Adeola (2012) in his study of Perceptions of Environmental Effects of Pesticides Use in Vegetable Production by Farmers in Ogbomoso, Nigeria, Also this was in the same line with. Damalas and Spyridon (2017) in their study about Farmers' Training on Pesticide usage. They reported that showed significantly higher levels of knowledge, beliefs about pesticide hazard control, and safety behaviors in pesticide use than nontrained farmers.

In relation to the age of studied sample and their level of total safety self-reported practice, Current study showed that there were highly statistical significant differences between total practice and age group, the current study results showed that the highest rate of satisfactory use of pesticide was among youngest age of farmers where $p_{-}$ value were $(0.0001,0.0001)$, in pre and posttest respectively. Compared with Magda et al (2016) in their study about "The Effect of Health Hazards Intervention on the Farmer's knowledge, Practice and Self-Reported Symptoms of Pesticides Exposure" showed that the highest rate of satisfactory use of pesticide was among youngest age of workers and least years of experience. The researcher suggest that may be related to the youngest farmers had high level of education and more motivated to adopt safety practices.

There was statistically significant relationship between educational level and satisfactory level of total safety practices among studied farmers before and after intervention. the results of the current study were in agreement with Farahat et al, (2009) who evaluated the effect of an educational intervention for farming families to protect their children from pesticide exposure, they found that the parents with high school or university degrees showed significantly greater improvements in knowledge and practice than parents who were illiterate or only able to read and write".

It also in the same line with jallow et al (2017) in their study about Pesticide Knowledge and Safety Practices among Farm Workers in Kuwait they found that Respondents with higher education levels were significantly less likely to store pesticides in their home $(20.89, \mathrm{p}<0.01)$. On the other hand it was found that the result of current study contradicted with the study of Sam et al., (2008) who studied "Effectiveness of an educational program to promote pesticide safety among pesticide handlers of South India". They pointed out that "the average baseline KAP score not influenced by educational level of farmers". The differences of the results in their study might be related to nearly half of studied workers have satisfactory level of education and had satisfactory knowledge about safe use of pesticide. The educated farmers were more initiated and motivated to adopt safety practices.

In this study found that there were positive statistically significant correlation between knowledge, attitudes and self-reported practices of pesticides' farmers after implementation of the health education program, have highest strong positive statistically significant correlation there were significant differences. These results come in the same line with Magda et al (2016) in their study found that there was a correlation between total knowledge and safety practice scores after intervention. Considering the findings of the current study were in contrast with Quinteiro et al (2013) in their study about "Analysis of pesticide application and applicator's training level in greenhouse farms in Galicia, Spain" they found that there was no correlation between training level and the implementation of good pesticide application practices.

In these study found that when studying the effect of socio-demographic data on farmer's practice towards safe use of pesticides "Level of user education, perceived Previous training " were was the most effective predictor that enhance their practice in pre and post-program. It was similarity to Okoffo et al, (2016) in their study about Pesticides exposure and the use of personal protective equipment by cocoa farmers in Ghana, found that the result of logistic regression to estimate the factors influencing farmers' decision to put on PPE when applying pesticides that Educational level had a positively significant $(\mathrm{p}<0.01)$.

These study found that when studying the effect of some variables on farmer's knowledge towards safe usage of pesticides 'Level of farmer's education and perceived previous training" Were the most effective predictors that enhance the knowledge of safe use of pesticides in preprogram only. This in the same line with Sa'ed et al, (2010) in their study about Knowledge and practices of pesticide use among farm workers in the West Bank, Palestine: safety implications, found that predictors of good pesticide knowledge were: secondary education level, college education level where value of Coefficient $\beta$ was (1.56) and $\mathrm{P}$ value was (0.009).

\section{Conclusion}

There was highly statistically significant improvement of farmer's knowledge, attitude and selfreported practices toward the safe usage of pesticides after implementation of the health education program.

\section{Recommendations}

The study recommend that:

- There is a need for a continuous planned educational and training program and offered on regular basis for farmers to improve their knowledge, attitude and practice regarding the safe usage of pesticides.

- Providing personal protective devices for farmers with reasonable prices to encourage them to take safety precautions. 
- Activate the role of occupational health nurse in agriculture sector by facilitating periodic visits for conducting health education programs.

- Further studies about farmers' health problems should be concerned.

\section{References}

[1]. Deji, S. A. (2012). Awareness of pesticide residues in locally available food and condiments among food sellers: a case study of Osun state, Nigeria. Journal of Public Health in Africa, 3(2), 26.

[2]. Khanal, G., \& Singh, A. (2016). Patterns of Pesticide Use and Associated Factors among the Commercial Farmers of Chitwan, Nepal. Environmental health insights, 10, EHIS40973.

[3]. Jørs, E. (2016). Acute Pesticide Poisoning Among Bolivian Small-Holder Farmers-Frequency, Risk Factors and Prevention. Odense, Denmark: Faculty of Health Sciences, University of Southern Denmark.

[4]. El-Wakeil, N., Shalaby, S., Abdou, G., \& Sallam, A. (2013). Pesticide-residue relationship and its adverse effects on occupational workers. In Insecticides-Development of Safer and More Effective Technologies. Intech.

[5]. Norkaew, S. (2009). Knowledge, attitude, and practice (KAP) of using personal protective equipment (PPE) for chilli-growing farmers in Huarua sub-district, Mueang district, Ubonrachathani province, Thailand (Doctoral dissertation, Chulalongkorn University).

[6]. Sam, K. G., Andrade, H. H., Pradhan, L., Pradhan, A., Sones, S. J., Rao, P. G., \& Sudhakar, C. (2008). Effectiveness of an educational program to promote pesticide safety among pesticide handlers of South India. International archives of occupational and environmental health, 81(6), 787-795.

[7]. Gaber. Sherine \& Abdel-Latif. Soha Hassan (2012), Effect of education and health locus of control on safe use of pesticides: a cross sectional random study, Journal of Occupational Medicine and Toxicology, 7, 1, p3.

[8]. Damalas, C. A., \& Koutroubas, S. D. (2017). Farmers' training on pesticide use is associated with elevated safety behavior. Toxics, 5(3), 19.

[9]. Magda Moawad Mohsen, Randa Salah Eldin Mohamed, Sameer Hamdy Hafez(2016). The Effect of Health Hazards Intervention on the Farmer's knowledge, Practice and Self-Reported Symptoms of Pesticides Exposure, International Journal of Novel Research in Healthcare and Nursing Vol. 3, Issue 2, pp.(196-209), Available at: www.noveltyjournals.com.

[10]. Farahat, T. M., Farahat, F. M., \& Michael, A. A. (2009). Evaluation of an educational intervention for farming families to protect their children from pesticide exposure. Eastern Mediterranean Health Journal, Vol. 15, No. 1.

[11]. Jallow, M. F., Awadh, D. G., Albaho, M. S., Devi, V. Y., \& Thomas, B. M. (2017). Pesticide knowledge and safety practices among farm workers in Kuwait: results of a survey. International journal of environmental research and public health, 14(4), 340.

[12]. Quinteiro, S. L., Pérez, M. M., Sobrino, C. C., \& Rioja, M. B. (2013). Analysis of pesticide application and applicator's training level in greenhouse farms in Galicia, Spain. Agricultural Economics Review, 14(2), 5.

[13]. Okoffo, E. D., Mensah, M., \& Fosu-Mensah, B. Y. (2016). Pesticides exposure and the use of personal protective equipment by cocoa farmers in Ghana. Environmental Systems Research, 5(1), 17.

[14]. Sa'ed, H. Z., Sawalha, A. F., Sweileh, W. M., Awang, R., Al-Khalil, S. I., Al-Jabi, S. W., \& Bsharat, N. M. (2010). Knowledge and practices of pesticide use among farm workers in the West Bank, Palestine: safety implications. Environmental health and preventive medicine, 15(4), 252 